\title{
Rectal Sarcoma
}

National Cancer Institute

\section{Source}

National Cancer Institute. Rectal Sarcoma. NCI Thesaurus. Code C5548.

A malignant soft tissue neoplasm that arises from the rectum. Representative examples include angiosarcoma, Kaposi sarcoma, and leiomyosarcoma. 